(C) 2006 Blackwell Verlag

No claim to original US government works

Journal compilation (C) 2006 Blackwell Verlag, Berlin

\title{
Effect of eggplant transformed with oryzacystatin gene on Myzus persicae and Macrosiphum euphorbiae
}

\author{
A. P. O. Ribeiro' ${ }^{1}$, E. J. G. Pereira ${ }^{2}$, T. L. Galvan², M. C. Picanço², E. A. T. Picoli ${ }^{1}$, D. J. H. da Silva ${ }^{3}$ M. G. Fári $^{4}$ \\ and W. C. Otoni ${ }^{1}$ \\ ${ }^{1}$ Departamento de Biologia Vegetal, ${ }^{2}$ Departamento de Biologia Animal, ${ }^{3}$ Departamento de Fitotecnia, \\ Universidade Federal de Viçosa, Viçosa, MG, Brazil; ${ }^{4}$ Department of Vegetable Crops \& Horticultural \\ Biotechnology, Debrecen University, Debrecen, Hungary
}

Ms. received: April 28, 2005; accepted: May 25, 2005

\begin{abstract}
The effect of a genetically modified eggplant line expressing oryzacystatin on Myzus persicae (Sulzer) and Macrosiphum euphorbiae (Thomas) was examined. The transgenic eggplant reduced the net reproductive rate $\left(R_{0}\right)$, the instantaneous rate of population increase $(r)$, and the finite rate of population increase $(\lambda)$ of both aphids species compared with a control eggplant line. The mean generation time $(T)$ of the aphids was unaffected by the transgenic plants. Age-specific mortality rates of $M$. persicae and $M$. euphorbiae were higher on transgenic plants. These results indicate that expression of oryzacystatin in eggplant has a negative impact on population growth and mortality rates of $M$. persicae and $M$. euphorbiae and could be a source of plant resistance for pest management of these aphids.
\end{abstract}

Key words: Solanum melongena, aphid, Hemiptera, pest management, plant resistance, proteinase inhibitor, transgenic

\section{Introduction}

The green peach aphid Myzus persicae (Sulzer) and the potato aphid Macrosiphum euphorbiae (Thomas) (Hom., Aphididae) are polyphagous phloem-feeding insects that commonly colonize a number of crop plants. They can cause both direct and indirect damage on cultivated eggplant, Solanum melongena L. Direct damage by these aphids include stunting of shoots and leaves, shoot dieback and leaf deformation. Indirect damage includes transmission of phytopathogenic viruses, promotion of sooty mold on the leaves and enhancement of weather damage to the fruit (Kennedy et al. 1962; Hill 1983; Minks and Harrewijn 1987; Gallo et al. 2002). These aphids occur on many crop species worldwide and can at times be serious pests (Blackman and Eastop 2000).

Unlike in temperate regions, in Brazil, M. persicae and $M$. euphorbiae colonies consist completely of females, and reproduction does not involve mating or egg laying (thelytokous parthenogenesis). Females give birth to live female nymphs that rapidly reach the reproductive phase. Dispersive alate morphs are produced when population density becomes high (M.C. Picanço, pers. obs.). Generations are overlapping and continuous throughout the year. Life cycle duration is usually short ranging from 16 to 50 days (Gallo et al. 2002). Because of this high capacity for reproduction and dispersion, high population densities are easily attained and efforts to suppress them are often necessary.
Plant resistance is an important component of integrated pest management that can reduce environmental pollution and costs associated with crop protection. The most direct forms of plant resistance are conferred by traits preventing access to plant tissue (antixenosis), or metabolically interfering with its digestion and assimilation (antibiosis), thus reducing herbivore performance and fitness (Maxwell and Jennings 1980). Few natural resistance sources are available for aphid control in Solanaceae. Hence, there has been a need to discover new effective genes which would offer resistance/protection against these pests. Extensive germplasm testing for insect resistance is usually costly and time-consuming. Thus, genetic transformation of eggplant with genes conferring resistance is an attractive alternative (Jouanin et al. 1998).

Transgenic-derived plant resistance is a subject welldocumented elsewhere (Strauss et al. 1991; Estruch et al. 1997; Jouanin et al. 1998; Sharma et al. 2000). Currently, strategies to improve plant resistance against insects through genetic transformation rely mostly on genes from the soil bacterium Bacillus thuringiensis $(\mathrm{Bt})$ or from plant protease inhibitors (PIs) (Jouanin et al. 1998). PIs are widely accepted because of their abundance and stability. They are usually highly specific for a particular class of digestive enzymes. PIs target mainly leaf-feeding insects, which use digestive proteases to cleave ingested proteins.

Aphids are thought to lack proteolytic activity in their digestive tract (Terra and Ferreira 1994; 
Mochizuki 1998) because of their diet (phloem sap), which is generally poor in proteins, and the presence of symbionts that supply them with essential amino acids (Douglas 1998). Some aphids are insensitive to many peptidic PIs (Rahbe and Febvay 1993), and therefore plant resistance strategies against phloem-feeding insects were first based on lectins (Gatehouse et al. 1996). Nevertheless, studies have shown that some PIs affect the growth or survival of aphids on artificial diets (Rahbé et al. 1995; Tran et al. 1997; Azzouz et al. 2005) or delivered through transgenic plants (Rahbé et al. 2003).

A well-known group of PIs are the cystatins, which are inhibitory proteins of cystein proteinases. These proteins have been identified in a variety of plant and animal species (Ryan 1990; Michaud 2000). The best characterized cystatin is the Oyzacystatin I (OC-I) protein (Atkinson et al. 1995) that was isolated and cloned from rice (Abe et al. 1987; Womack et al. 2000). OC-I has successfully been used against pests possessing cysteine proteases, either coleopteran insects (Leple et al. 1995; Lecardonnel et al. 1999) or nematodes (Urwin et al. 1995).

Although the exact mode of action of PIs is not yet fully understood, their ingestion by sensitive insects can delay growth and development, reduce fecundity and cause mortality, thus leading to reduced population growth and survival (Rahbé et al. 2003; Azzouz et al. 2005). Insect performance in the presence and absence of PIs can be determined by comparing rates of population increase. Similarly, postembryonic mortality can be studied by following cohorts for a lifetime and comparing the age-specific mortality schedule.

Life tables constitute simple, efficient and powerful tools for analysing and understanding the effect that a resistance factor has upon population growth and mortality schedule of an insect population (SilveiraNeto et al. 1976; Southwood 1978; Carey 2001; Perdikis and Lykouressis 2002). Fertility life-table data allow estimation of population growth rates, the socalled demographic parameters. The classical life table, or life expectancy table, uses tools borrowed from demography and the actuarial sciences to analyse the mortality experience of cohorts.

This study was designed to evaluate the effect of oryzacystatin $I$ gene products present in a transgenic eggplant line against two species of aphids employing age-specific fertility and life tables.

\section{Materials and Methods}

Two eggplant genotypes were investigated: a Brazilian commercial variety named Embú and its transgenic counterpart. Transgenic plants were obtained using vector pOZC6 (containing coding regions of the oryzacystatin, $\beta$-glucuronidase and neomycin fosfotransferase II genes).

To identify transformed plants, DNA was extracted from 15-day-old leaves following a protocol described by Fulton et al. (1995). Primary transformants were selected based on the polymerase chain reaction (PCR). The following primers were used for amplification reactions: NPTr (5'-GCGGTCAGCCCATTCGCCGCC- $3^{\prime}$ ) and NPTf (5'-TCAGCGCAGGGGCGCCCGGTT-3') for $n p t$ II gene (neomicin fosfotransferase II), and GUSr (5'-TTTAACTATGCCGGGATCCATCCATCGA-3') and GUSf (5-'CCAGTCGAGCATCTCTTCAGCGTA-3') for uidA ( $\beta$-glucuronidase) gene. A histochemical gus gene assay was also used, as described by Brasileiro and Carneiro (1998).

Transformed plants carrying oryzacystatin were selected and allowed to grow and produce seeds. Non-transformed plants were also grown to be used as control in the plant evaluations. Seeds of the two groups of plants were harvested, sowed and allowed to self-fertilize. The $R_{2}$ progenies produced were assayed by PCR for presence of $n p t \mathrm{II}$ and gus genes. Histochemical gus assay was also performed. Sixteen individuals of each $\mathrm{R}_{2}$ homozygous transgenic and nontransgenic plants were evaluated against $M$. persicae and M. euphorbiae.

Plant evaluation assays were conducted in a $2 \times 2$ factorial scheme (two eggplant lines and two aphid species). The experimental design was completely randomized with eight replicates for each treatment combination. A polyethylene plastic pot (5 1 capacity) containing one eggplant plant constituted the experimental unit. Seeds were germinated in horticultural organic substrate (Plantmax ${ }^{\circledR}$; BioPlant Agrícola Ltda., Nova Ponte, Brazil), and plants were grown under greenhouse conditions. Plants used had uniform height (approximately $50 \mathrm{~cm}$ ). During the experiment set-up, leaves were enclosed in small-mesh cloth bags $(20 \times 28 \mathrm{~cm})$, and 10 1-day-old aphids obtained from field-grown, infested tomato plants were released on the adaxial surface of the leaf. Six hours after release of the insects (day 0) and thereafter every 3 days, the number of alive aphids, their stage of development, and the number of nymphs produced were recorded until the entire cohort had died. In each evaluation date, neonate nymphs and dead individuals were removed in order to avoid miscounting in the next evaluation date.

The life-table format (Southwood 1978; Carey 1993) was used to study numerical changes in the cohorts of $M$. persicae and $M$. euphorbiae and their age-specific mortality when feeding on the eggplant lines. Fertility table values were calculated using methods described by Birth (1948) and Carey (1993). The intrinsic rate of increase was obtained by iteration of the Lotka equation (Birth 1948): $\sum \mathrm{e}^{-\mathrm{r} x} l_{x} m_{x}=1$, where $x$ is the pivotal age class, $l_{x}$ is the survivorship at pivotal age $x$, and $m_{x}$ is the number of nymphs produced by all aphids alive at each pivotal age $x$. The net reproductive rate or rate of multiplication per generation, $R_{0}=\sum\left(l_{x} m_{x}\right)$, the mean generation time, $T=\ln \left(R_{0}\right) / r$, and the finite rate of increase or rate of multiplication per day, $\lambda=\ln (r)$ were also estimated. The life expectancy table was computed as described by Carey (2001) and included: fraction alive at age $\times\left(l_{x}\right)$; death distribution $\left(d_{x}\right)$, the fraction of the original cohort dying between $x$ and $x+1$; and age-specific mortality $\left(100 q_{x}\right)$, which is the mortality rate per age interval expressed as the rate per cent alive at the start of that interval, $100 q_{x}=\left(d_{x}\right)$ $\left.l_{x}\right) \times 100$.

Age-specific fertility tables were constructed and the population statistics $R_{0}, r$ and $T$ were calculated for each replication. A two-way analysis of variance was conducted on the population statistics using the mixed procedure (Proc Mixed, SAS Institute 2002). Residual analysis of the data using the univariate and qplot procedures (Proc Univariate, Proc Gplot, SAS Institute 2002) combined with use of Levene's $F$ and Kolmogov-Sminorv tests (Snedecor and Cochran 1989) were employed to ensure that the assumptions of homogeneity of variances and normality were met before data were analysed. For the age-specific mortality schedule, the mean of the frequency distribution of deaths and its standard deviation were computed (Carey 1993), and 95\% 
Table 1. Results of the analysis of variance conducted on the population growth statistics of Myzus persicae and Macrosiphum euphorbiae feeding on transgenic and non-transgenic eggplants

\begin{tabular}{|c|c|c|c|c|c|c|}
\hline \multirow[b]{2}{*}{ Source } & \multicolumn{2}{|c|}{$R_{0}^{1}$} & \multicolumn{2}{|c|}{$r^{2}$} & \multicolumn{2}{|c|}{$T^{3}$} \\
\hline & F-value & P-value & F-value & P-value & F-value & P-value \\
\hline $\begin{array}{l}\text { Eggplant line } \\
\text { (A) }\end{array}$ & 7.48 & 0.011 & 8.42 & 0.007 & 0.02 & 0.884 \\
\hline $\begin{array}{l}\text { Aphid species } \\
\text { (B) }\end{array}$ & 9.54 & 0.005 & 16.33 & 0.000 & 10.74 & 0.003 \\
\hline $\begin{array}{l}\text { Interaction } \\
\mathrm{A} \times \mathrm{B}\end{array}$ & 0.08 & 0.785 & 0.81 & 0.376 & 2.31 & 0.140 \\
\hline $\begin{array}{l}{ }^{1} \text { Net reproduct } \\
{ }^{2} \text { Instantaneous } \\
\text { 3ne interval }\end{array}$ & $\begin{array}{l}\text { tive rate } \\
\mathrm{s} \text { rate of } \\
\text { l betweer }\end{array}$ & $\begin{array}{l}\text { populati } \\
\text { a generati }\end{array}$ & $\begin{array}{l}\text { on incre } \\
\text { ions. }\end{array}$ & ase. & & \\
\hline
\end{tabular}

confidence intervals for age-specific mortality rates were constructed (Carey 2001). The effect of the transformed eggplant on the postembryonic survivorship of the aphids was analysed using the Pearson's chi-squared test.

The experiments were carried out based on ongoing biosafety regulations, as required by the Comissão Técnica Nacional de Biossegurança (CTNBio), and all transgenic material involved was discarded by incineration.

\section{Results}

To investigate the effect of an eggplant line transformed with the oryzacystatin gene on population growth of $M$. persicae and $M$. euphorbiae, eight cohorts of 10 aphids caged on eggplant leaves were followed for one generation and age-specific fertility tables constructed. Population growth statistics were calculated for each replication and analysed by ANOva.

The results of the analysis of variance are presented in table 1. Significant effect $(\mathrm{P}<0.05)$ of eggplant line was detected upon population growth rates but not on generation time $(T)$, indicating that population growth of the aphids varied according to the eggplant line they fed on although their generation time did not change. The interaction of aphid species with eggplant line was negligible $(\mathrm{P}>0.05)$ for all quantities of the fertility table indicating that $M$. persicae and $M$. euphorbiae were similarly affected by the eggplant lines. The generation time and population growth rates of the aphid species were different regardless of the eggplant line they fed on, as indicated by the significant effect of aphid species on these fertility life quantities (table 1).

Transgenic eggplant reduced population growth rates of $M$. persicae and $M$. euphorbiae (table 2). Except for the generation time, there were significant differences in all the population growth statistics of aphids feeding on transgenic plants when compared with those feeding on control plants. The net reproductive rate $\left(R_{0}\right)$ of $M$. persicae and $M$. euphorbiae were reduced by 5.85 and 4.77 aphids per generation, respectively, on transgenic plants. This represents an average reduction of $46 \%$ and $77 \%$ in the number of aphids of M. persicae and M. euphorbiae produced per generation respectively. The instantaneous rate of population increase $(r)$ of $M$. persicae on transgenic plants was $70 \%$ of that on control plants. For $M$. euphorbiae, this effect was even greater as the $r$ value was reduced to a negative value in the transgenic eggplant, indicating that the population was incapable of growing and would eventually be extinct over successive generations (table 2). As a consequence of reduced instantaneous rate of increase, the finite rate of increase $(\lambda)$ of the aphids, which represents the number of times that a population multiplies per day was also reduced. $M$. persicae and $M$. euphorbiae produced significantly less offspring per day that would make to adulthood when feeding on transgenic eggplant (table 2).

To study the effect of oryzacystatin on the mortality of $M$. persicae and $M$. euphorbiae, age-specific life tables were constructed (summarized in fig. 1a-h). There was a negative effect of the transgenic plants on the mortality schedule of the two aphid species as, in general, all the age-specific life-table functions had lower values for aphids feeding on transgenic plants (fig. $1 \mathrm{a}-\mathrm{h}$ ).

The survivorship curves ( $l_{x}$ vs. age) of aphids feeding on eggplant transformed with the oryzacystatin gene were located below the ones for aphids feeding on control plants (fig. 1a,b) indicating higher mortality of aphids feeding on the transgenic plants. Chi-squared analysis confirmed that the transgenic eggplant significantly reduced the survivorship of $M$. persicae

Table 2. Comparison of population growth statistics of Myzus persicae and Macrosiphum euphorbiae on control and transgenic eggplant expressing oryzacystatin

\begin{tabular}{|c|c|c|c|c|}
\hline \multirow[b]{3}{*}{ Quantity $^{2}$} & \multicolumn{4}{|c|}{ Estimate $^{1}$} \\
\hline & \multicolumn{2}{|c|}{ M. persicae } & \multicolumn{2}{|c|}{ M. euphorbiae } \\
\hline & Control & Transgenic & Control & Transgenic \\
\hline$R_{0}$ & $12.70 \pm 2.55$ & $6.85 \pm 2.14^{*}$ & $6.16 \pm 1.92$ & $1.39 \pm 0.58^{*}$ \\
\hline$r$ & $0.160 \pm 0.017$ & $0.113 \pm 0.034^{*}$ & $0.087 \pm 0.019$ & $-0.002 \pm 0.020^{*}$ \\
\hline$\lambda$ & $1.175 \pm 0.019$ & $1.085 \pm 0.065$ & $1.092 \pm 0.021$ & $0.999 \pm 0.020$ \\
\hline$T$ & $14.52 \pm 0.78$ & $12.55 \pm 1.07$ & $16.60 \pm 1.00$ & $18.23 \pm 1.69$ \\
\hline
\end{tabular}



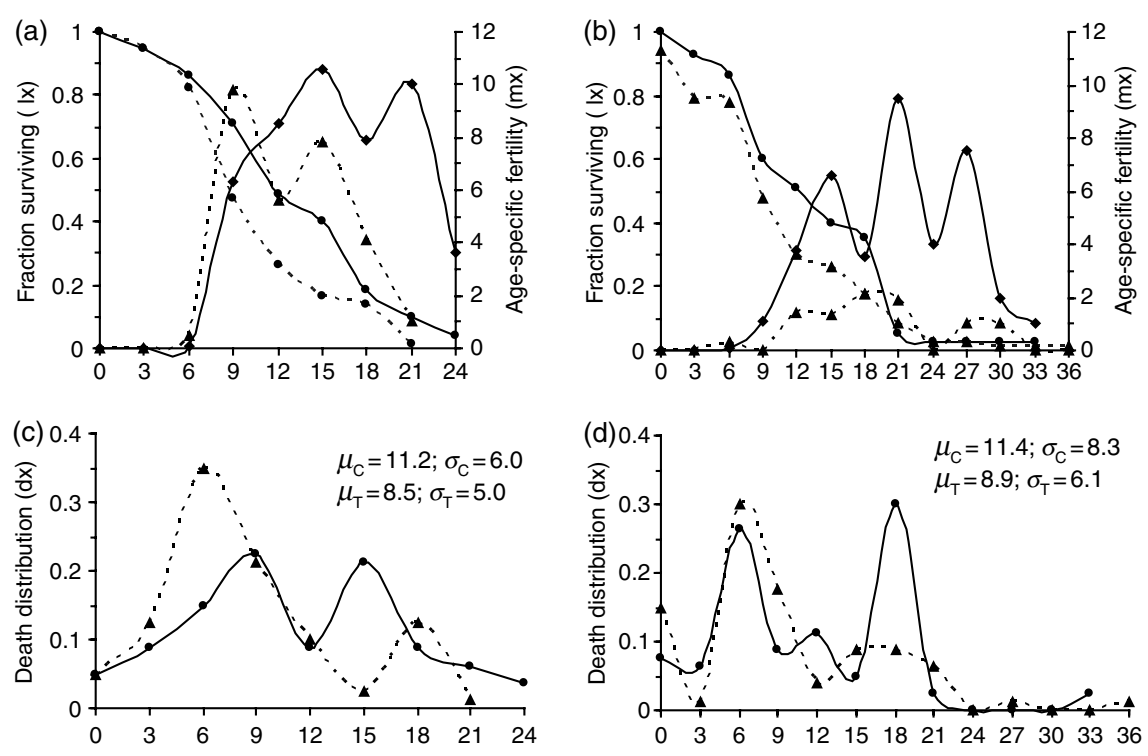

Fig. 1. Age-specific life table functions of Myzus persicae (a, $c$, and $e)$, and Macrosiphum euphorbiae $(b, d$, and $f)$ on control and transgenic eggplant expressing oryzacystatin. Error bars represent $95 \%$ confidence intervals of agespecific mortality
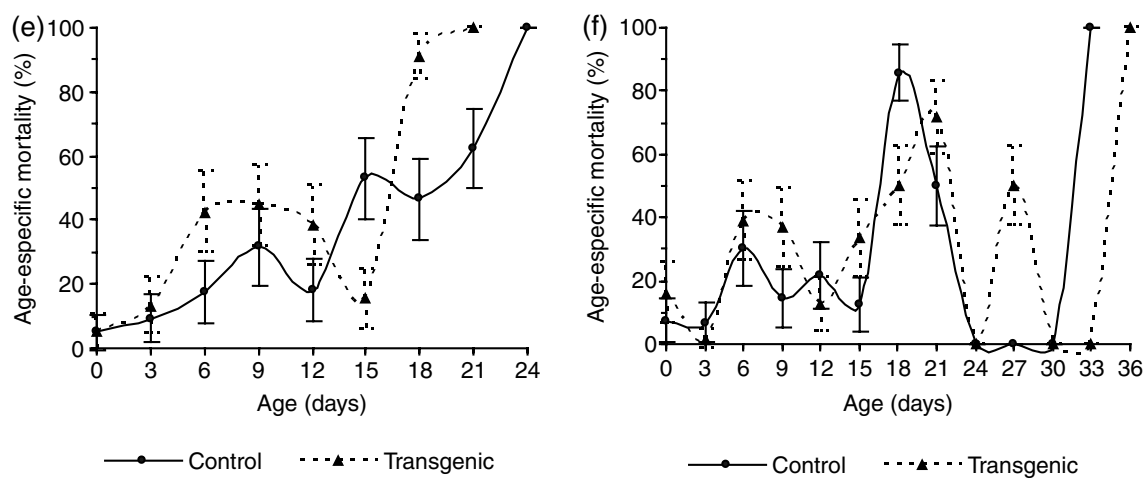

$\left(\chi_{8}^{2}=36.31, \quad \mathrm{P}<0.01\right)$ and $M$. euphorbiae $\left(\chi_{11}^{2}=\right.$ 25.83, $\mathrm{P}=0.007)$ compared with control plants. Mortality of $M$. persicae and M. euphorbiae accelerated at intermediate ages and slowed down at older ages (fig. 1a,b). The age-specific fertility schedule $\left(m_{x}\right.$ vs. age) of aphids feeding on transgenic plants was also lower, especially for M. euphorbiae (fig. 1a,b), indicating a strong effect on the reproduction of this aphid. The death distribution $\left(d_{x}\right)$, which represents the fraction of the original cohort dying between $x$ and $x+1$, had in general one peak around 6 days and the another around 18 days for both aphid species, but death peaks of aphids feeding on transgenic plants tended to be higher and occur early (fig. 1c,d). The longevity (mean age of death) of the aphids was statistically unaffected by feeding on transgenic plants although it tended to be shortened as indicated by the lower values of the mean and standard deviation of age of death of the aphids feeding on this plant (fig. 1c,d). Age-specific mortality rates $\left(100 q_{x}\right)$ were significantly higher for aphids feeding on transgenic plants, especially in early and late ages as indicated by nonoverlapping 95\% confidence intervals (fig. $1 \mathrm{~g}$, h).

\section{Discussion}

Population growth and survival of $M$. persicae and $M$. euphorbiae were reduced by transgenic plants transformed with the $O C-I$ gene. Previous studies have also identified that some proteinase inhibitors affect the growth or survival of aphids on artificial diets (Rahbé et al. 1995; Tran et al. 1997; Azzouz et al. 2005) and delivered through transgenic plants (Rahbé et al. 2003). Aphids were thought to lack proteolytic activity in their digestive tract because they feed strictly on protein-poor phloem (Terra and Ferreira 1994; Mochizuki 1998). However, recently, Deraison et al. (2004) demonstrated protease activity in gut extracts from Aphis gossypii and identified that its major intestinal endoproteases are of the cysteine type.

In M. persicae, Rahbé et al. (2003) identified OC-I associated with decrease in activity of a major cysteine protease in whole body extracts. Oryzacystatin was distributed along the gut epithelium and also associated with $M$. persicae bacteriocytes (Rahbé et al. 2003), which harbour obligate intracellular symbionts critical for aphid nutrition and reproduction (Douglas 1998). The effect of oryzacystatin on $M$. persicae and $M$. euphorbiae found in the present study could be attributed to disruption of cysteine proteinases either present in their digestive tracts or involved in development and reproduction (Rahbé et al. 2003). Characterization of proteinase activity in gut extracts may help clarify the involvement of cysteine proteinases in digestive processes of these aphids.

Our findings of cystatin reducing the reproductive performance and survival of $M$. euphorbiae in planta are in agreement with those obtained in artificial diet (Azzouz et al. 2005), in which oryzacystatin prevented reproduction and reduced nymphal survival of M. euphorbiae. On potatoes expressing OCI, however, 
the performance of $M$. euphorbiae improved significantly although the enhanced performance may not be related to the inhibitory action of the cystatin (Ashouri et al. 2001). In the present study, we observed a drastic effect on reproduction (see plot of age-specific fertility, fig. 1b) suggesting that a cysteine proteinase important in this process may have been disrupted. Direct test of this hypothesis will require refined proteinase assays in different tissues as well as immunoassays to detect accumulation of oryzacystatin in reproductive organs. Even though the non-significant interaction between aphid species and eggplant line (table 1) indicated a statistically similar effect of the transgenic eggplant on the two aphid species, $M$. euphorbiae tended to be more affected by the transgenic eggplant than $M$. persicae as the reduction in population growth rates of M. euphorbiae appear to be greater (table 2).

The effect of oryzacystatin reducing the reproductive performance and mortality of $M$. persicae and $M$. euphorbiae provides indirect evidence of the expression of oryzacystatin in the phloem sap of the transformed plants although indirect effects of OC-I expression on aphid performance through modification of phloem physiology because of the pleiotropic effects of transgene expression cannot be excluded (GutierrezCampos 2001). This possibility, however, is unlikely because proteins encoded by marker fusion genes have been observed to enhance aphid performance (Alla et al. 2003) and not to reduce it as we observed in the present study. Besides, the effect we observed here is very similar to the effect of oryzacystatin in conditions of controlled exposure (Azzouz et al. 2005), which makes it hard to believe that the reduced performance of the aphids could be due to some other protein. Detection of oryzacystatin in the phloem sap of transformed plants or honeydew of phloem-feeding insects can provide confirmation of its expression in planta.

Our estimates of population growth rates of $M$. persicae on control eggplant are comparable with those reported on Lactuca sativa varieties (Ricci et al. 1999). On cabbage (Brassica oleracea), Anil and Singh (1997) reported generation time $(T)$ of 28.31 days and instantaneous rate of increase $(r)$ of 0.153 . Moreover, Bastos et al. (1996) reported values for $T$ and $r$ of 14.33 days and 0.237 respectively for cabbage.

In the present study, there was difference between $M$. euphorbiae and $M$. persicae with respect to their population dynamics. Overall, $M$. euphorbiae had lower population growth rates than $M$. persicae. This is not unexpected because $M$. persicae is smaller than $M$. euphobiae, which can confer the former faster development and higher $r$ (Clark et al. 1967; Price 1997). The higher proportion of survivors of M. persicae reaching the adult phase (when first nymphs are produced) could also have contributed to its higher $r$ (fig. 1a,b).

Taken together, the results of this study suggest that transformation of eggplant with the oryzacystatin gene has a negative impact on the population growth of aphids and could be a reliable source of plant resistance for pest management of $M$. persicae and M. euphorbiae. Other genes have also been studied aiming plant resistance against these aphids, for example, the $M e u-1$ gene, which conferred partial resistance against $M$. euphorbiae and nematodes (Vos et al. 1998). In addition, GNA (Galanthus nivalis) expression in tobacco led to additional protection against M. persicae (Hilder et al. 1995), and in potato against M. persicae and Aulacorthum solani (Hom., Aphididae) (Down et al. 1996; Gatehouse et al. 1996). Among the alternatives available to create aphidresistant transgenic plants, PIs appear to be very promising. Aphids, however, represent a group of insect pests difficult to efficiently control by means of current host-plant resistance strategies and their management is dependent on other mortality factors including natural enemies. For this reason, it is important to further investigate possible effects of PIs on aphidophagous and other non-target arthropods in scenarios where they are expressed in planta (Schuler et al. 2001; Cowgill et al. 2004) and in conditions of controlled exposure (Azzouz et al. 2005 ) in order to rationally integrate this type of transgenic-derived plant resistance in pest management programmes.

\section{Acknowledgements}

The authors thank Dr Istvan Nagy (Agricultural Biotechnology Center, Göddöllo, Hungary) for providing the vector pOZC6, and CAPES (Coordenação de Aperfeiçoamento de Pessoal de Nível Superior, Brazil) and CNPq (Conselho Nacional de Desenvolvimento Científico e Tecnológico, Brazil) for providing scholarships.

\section{References}

Abe K, Emori Y, Kondo H, Suzuki K, Arai S, 1987. Molecular cloning of a cysteine proteinase inhibitor of rice (oryzacystatin). Homology with animal cystatins and transient expression in the ripening process of rice seeds. J. Biol. Chem. 262, 16793-16797.

Alla S, Cherqui A, Kaiser L, Azzouz H, Sangwann-Norreel B, Giordanengo P, 2003. Effects of potato plants expressing the nptII-gus fusion marker genes on reproduction, longevity, and host finding of the peach-potato aphid, Myzus persicae. Entomol. Exp. Appl. 106, 95-102.

Anil S, Singh G, 1997. Life table studies of Myzus persicae (Sulzer) (Homoptera: Aphidae) on cauliflower Brassica oleracea var. botrytis. Pest Manag. Hortic. Ecosyst. 3, $75-78$.

Ashouri A, Michaud D, Cloutier C, 2001. Unexpected effects of different potato resistance factors to the Colorado potato beetle (Coleoptera: Chrysomelidae) on the potato aphid (Homoptera: Aphididae). Environ. Entomol. 30, 524-532.

Atkinson HJ, Urwin PE, Hansen E, McPherson MJ, 1995. Designs for engineered resistance to root-parasitic nematodes. Dis. Pest Resist. 13, 369-374.

Azzouz H, Cherqui A, Campan E. DM, Rahbé Y, Duport G, Jouanin L, Kaiser L, Giordanengo P, 2005. Effects of plant protease inhibitors, oryzacystatin I and soybean Bowman-Birk inhibitor, on the aphid Macrosiphum euphorbiae (Homoptera, Aphididae) and its parasitoid Aphelinus abdominalis (Hymenoptera, Aphelinidae). J. Insect Physiol. 51, 75-86.

Bastos CS, Picanço MC, Leite G. LD, Araújo JM, 1996. Tabelas de fertilidade e de esperança de vida de Myzus 
persicae (Sulzer) (Homoptera: Aphididae) em couvecomum. Científica, 24, 187-197.

Birth LC, 1948. The instantaneous rate of natural increase of an insect population. J. Anim. Ecol. 17, 15-26.

Blackman RL, Eastop VF, 2000. Aphids on the World's Crops - An Identification and Information Guide. 2nd edn. Chichester: Wiley.

Brasileiro A. CM, Carneiro V. TC, 1998. Manual de transformação genética de plantas. Brasília: CENARGEN - SPI.

Carey JR, 1993. Applied Demography for Biologists with Special Emphasis on Insects. New York: Oxford University Press.

Carey J, 2001. Insect biodemography. Annu. Rev. Entomol. 46, 79-110.

Clark LR, Geier PW, Hughes RD, Morris RF, 1967. The Ecology of Insect Populations in Theory and Practice. London: Methuen and Co.

Cowgill SE, Danks C, Atkinson HJ, 2004. Multitrophic interactions involving genetically modified potatoes, nontarget aphids, natural enemies and hyperparasitoids. Mol. Ecol. 13, 639-647.

Deraison C, Darboux I, Duportets L, Gorojankina T, Rahbé Y, Jouanin L, 2004. Cloning and characterization of a gut-specific cathepsin L from the aphid Aphis gossypii. Insect Mol. Biol 13, 165-177.

Douglas AE, 1998. Nutritional interactions in insect-microbial symbiosis: aphids and their symbiotic bacteria. Buchnera. Annu. Rev. Entomol. 43, 17-37.

Down RE, Gatehouse A. MR, Hamilton W. DO, Gatehouse JA, 1996. Snowdrop lectin inhibits development and decreases fecundity of the glasshouse potato aphid (Aulacorthum solani) when administered in vitro and via transgenic plants both in laboratory and glasshouse trials. J. Insect Physiol. 43, 727-739.

Estruch JJ, Carozzi NB, Desai N, Duck NB, Warren GW, Koziel MG, 1997. Transgenic plants: an emerging approach to pest control. Nature Biotechnol. 15, 137141.

Fulton T, Chunwongse J, Tanksley SD, 1995. Microprep protocol for extraction of DNA transfer genes. Science 273, 1107-1109.

Gallo D, Nakano O, Silveira-Neto S, Carvalho R. PL, Baptista GC, Berti-Filho E, Parra J. RP, Alves SB, Vendramin JD, Marchini LC, Lopes J. RS, Omoto C, 2002. Entomologia Agrícola. Piracicaba (Brazil): FEALQ.

Gatehouse AMR, Down RE, Powell KS, Sauvion N, Rahbe Y, Newell CA, Merryweather A, Hamilton W. DO, Gatehouse JA, 1996. Transgenic potato plants with enhanced resistance to the peach-potato aphid Myzus persicae. Entomol. Exp. Appl. 79, 295-307.

Gutierrez-Campos R, 2001. Pleiotropic effects in transgenic tobacco plants expressing the oryzacystatin I gene. HortScience 36, 118-119.

Hilder VA, Powell KS, Gatehouse AMR, Gatehouse JA, Gatehouse LN, Shi Y, Hamilton WDO, Merryweather A, Newell CA, Timons JC, Peumons WJ, von Domme E, Boulter D, 1995. Expression of snowdrop lectin in transgenic tobacco plants results in added protection against aphids. Transg. Res. 4, 18-25.

Hill DS, 1983. Agricultural Insect Pests of the Tropics and their Control, 2nd edn. Cambridge: Cambridge University Press.

Jouanin L, Bonadé-Bottino M, Girard C, Morrot G, Giband M, 1998. Transgenic plants for insect resistance. Plant Sci. 131, 1-11.
Kennedy JS, Day MF, Eastop VF, 1962. A Conspectus of Aphids as Vectors of Plant Viruses. London: Commonwealth Agricultural Bureaux.

Lecardonnel A, Chauvin L, Jouanin L, Beaujean A, Prevost G, Sangwan-Norreel B, 1999. Effects of rice cystatin I expression in transgenic potato on Colorado potato beetle larvae. Plant Sci. 140, 71-79.

Leple JC, Bonade-bottino M, Augustin S, Pilate G, Letan VD, Delplanque A, Cornu D, Jouanin L, 1995. Toxicity to Chrysomela tremulae (Coleoptera, Chrysomelidae) of transgenic poplars expressing a cysteine proteinase inhibitor. Mol. Breed. 1, 319-328.

Maxwell FG, Jennings PR, 1980. Breeding Plants Resistant to Insects. New York: Wiley.

Michaud JP, 2000. Recombinant Protease Inhibitors in Plants. Austin: Landes Bioscience.

Minks AK, Harrewijn P, 1987. Aphids - their Biology, Natural Enemies and Control. Amsterdam: Elsevier.

Mochizuki A, 1998. Characteristics of digestive proteases in the gut of some insect orders. Appl. Entomol. Zool. 33, 401-407.

Perdikis D. Ch, Lykouressis DP, 2002. Life table and biological characteristics of Macrolophus pygmaeus when feeding on Myzus persicae and Trialeurodes vaporariorum. Entomol. Exp. Appl. 102, 261-272.

Price PW, 1997. Life histories and reproductive strategies. In: Insect Ecology. Ed. by Price PW. New York: John Wiley and Sons, pp. 341-374.

Rahbe Y, Febvay G, 1993. Protein toxicity to aphids - an in vitro test on Acyrthosiphon pisum. Entomol. Exp. Appl. 67, 149-160.

Rahbé Y, Sauvion N, Febvay G, Peumans WJ, Gatehouse A. MR, 1995. Toxicity of lectins and processing of ingested proteins in the pea aphid Acyrthosiphon pisum. Entomol. Exp. Appl. 76, 143-155.

Rahbé Y, Deraison C, Bonadé-Bottino M, Girard C, Nardon C, Jouanin L, 2003. Effects of the cysteine protease inhibitor oryzacystatin (OC-I) on different aphids and reduced performance of Myzus persicae on OC-I expressing transgenic oilseed rape. Plant Sci. 164, 441-450.

Ricci EM, Vasicek A, Rossa FRLA, La Rossa FR, 1999. Life cycle stages of Myzus persicae (Sulzer) (Homoptera: Aphididae) on three lettuce cultivars. Proceedings of the meeting on soil and water conservation technologies for Smallholders in hillside agriculture. 1998. CEIBA 40, 6971.

Ryan CA, 1990. Protease inhibitors in plants: genes for improving defenses against insects and pathogens. Annu. Rev. Phytopathol. 28, 425-449.

SAS Institute, 2002. SAS Users' Guide, version 8.1. Cary, NC: SAS Institute.

Schuler T. HO, Denholm I, Jouanin L, Clark SJ, Clark AJ, Poppy GM, 2001. Population-scale laboratory studies of the effect of the effects of transgenic plants on non-target insects. Mol. Ecol. 10, 1845-1853.

Sharma HC, Sharma KK, Seetharama N, Ortiz R, 2000. Prospects for using transgenic resistance to insects in crop improvement. Electronic J. Biotechnol. 3, 1-20.

Silveira-Neto S, Nakano O, Barbin D, Villa-Nova NA, 1976. Manual de Ecologia de Insetos, edn. Piracicaba: Agronômica CERES.

Snedecor GW, Cochran WG, 1989. Statistical Methods, 8th edn. Ames, IA: Iowa State University Press.

Southwood T. ER, 1978. Ecological Methods. London: Chapman and Hall.

Strauss SH, Howe GT, Goldfarb B, 1991. Prospects for genetic engineering of insect resistance in forest trees. Forest Ecol. Manag. 43, 181-209. 
Terra WR, Ferreira C, 1994. Insect digestive enzymes: properties, compartmentalization and function. Comp. Biochem. Physiol. 109, 162.

Tran P, Cheesbrough TM, Keickhefer RW, 1997. Plant proteinase inhibitors are potential anticeral aphid compounds. J. Econ. Entomol. 90, 1672-1677.

Urwin PE, Atkinson HJ, Waller DA, McPherson MJ, 1995. Engineered oryzacystatin-I expressed in hairy roots confers resistance to Globodera pallida. Plant J. 8, 121-131.

Vos P, Simons G, Jesse T, Wijbrandi J, Heinen L, Hogers R, Frijters A, Groenedijk J, Diergaarde P, Reijans M,
Fierens-Onstenk J, de Both M, Peleman J, Liharska T, Hontelez J, Zabeau M, 1998. The tomato Mi-1 gene confers resistance to both root-knot nematodes and potato aphids. Nature Biotechnol. 16, 1365-1369.

Womack JS, Randall J, Kemp JD, 2000. Identification of a signal peptide for oryzacystatin-I. Planta 210, 844-847.

Author's address: Wagner C. Otoni, (corresponding author), W.C.O. Plant Biology Department, Federal University of Viçosa, University Campus, 36570-000, Viçosa, MG, Brazil. E-mail: wotoni@ufv.br 